\title{
Article
}

\section{Exhaled Nitric Oxide Level in Pharynx Angioedema}

\author{
Lukasz Moos ${ }^{1}$, Magdalena Zajac ${ }^{2,3}$ and Zenon Brzoza $1, * \mathbb{D}$ \\ 1 Department of Internal Diseases with Division of Allergology, Institute of Medical Sciences, University of \\ Opole, 45-040 Opole, Poland; lukasz.moos@uni.opole.pl \\ 2 European Center for Diagnosis and Treatment of Urticaria (GA2LEN UCARE), 41-800 Zabrze, Poland; \\ magdalenazajac2000@gmail.com \\ 3 Medical University of Wroclaw, 50-367 Wroclaw, Poland \\ * Correspondence: zbrzoza@mp.pl
}

Citation: Moos, Ł.; Zajac, M.; Brzoza, Z. Exhaled Nitric Oxide Level in Pharynx Angioedema. J. Clin. Med. 2022, 11, 637. https://doi.org/ $10.3390 / j \mathrm{~cm} 11030637$

Academic Editor:

Antonio Spanevello

Received: 18 December 2021

Accepted: 25 January 2022

Published: 27 January 2022

Publisher's Note: MDPI stays neutral with regard to jurisdictional claims in published maps and institutional affiliations.

Copyright: () 2022 by the authors Licensee MDPI, Basel, Switzerland. This article is an open access article distributed under the terms and conditions of the Creative Commons Attribution (CC BY) license (https:// creativecommons.org/licenses/by/ $4.0 /)$.

\begin{abstract}
Airway inflammation is related to increased nitric oxide production. It can be assessed noninvasively with exhaled nitric oxide measurement. As airway inflammation was supposed to be present in chronic urticaria and angioedema patients we hypothesized increased exhaled nitric oxide in this group. Twenty-six symptomatic chronic urticaria patients with an acute episode of pharynx angioedema (17 women and 9 men, median age 35 ) were included in the study group. None of the patients reported a history of asthma, allergic rhinitis or cigarette smoking. The control group consisted of 29 non-smoking healthy subjects (19 women and 10 men, median age 22) without any history of atopy. Exhaled nitric oxide measurement was performed in all subjects. Exhaled nitric oxide levels in the angioedema group did not differ statistically significantly from those detected in healthy subjects (15.5 ppb and $17.0 \mathrm{ppb}$ respectively). Our results indicate the lack of airway inflammation in chronic urticaria patients with pharynx angioedema.
\end{abstract}

Keywords: angioedema; chronic urticaria; nitric oxide

\section{Introduction}

Nitric oxide (NO) is generated from l-arginine by different isoforms of synthases. Contrary to endothelial (eNOS or NOS-3) and neural (nNOS or NOS-1) isoforms, one form of NO synthase, i.e., inducible and calcium-dependent (iNOS or NOS-2) is not expressed in normal conditions. Constitutively expressed synthases produce NO as a result of receptor stimulation whereas iNOS is expressed in response to diverse stimuli such as inflammatory cytokines having microbidial and pro-inflammatory effects [1,2]. Constitutive forms of synthases are responsible for vasodilatation and erythema [3].

Therefore, NO may produce beneficial or adverse effects in humans. It expresses proinflammatory activity including increased vascular permeability [4]. On the other hand, when inhibiting mast cell degranulation NO shows an anti-inflammatory activity [5]. The pro- or anti-inflammatory properties of NO may vary according to different conditions $[1,4]$.

It is well established that NO is produced by different cells such as macrophages and epithelial cells $[4,6-8]$. Recent studies show NO production in mast cells in response to different infections [9-11]. The exhaled NO (eNO) level is a marker of NO production in the respiratory tract [12-14]. Its level correlates with the intensity of airway inflammation. As it is present in the respiratory tract epithelium and cells that take part in inflammation, $\mathrm{NO}$ is used as a marker of type 2 airway inflammation [12,15]. The increased level of eNO -measured as fractional exhaled NO (FeNO) or alveolar concentration of $\mathrm{NO}$ (CaNO) was proven in patients suffering from asthma, rhinitis as well as bronchiectasis and interstitial lung disease [12-14,16,17]. Additionally, it was proven to be raised in patients with scleroderma and sarcoidosis, although the usefulness of FeNO and CaNO measurements in those conditions remains inconclusive $[18,19]$. We were the first to analyze and prove the increased nitric oxide level in patients with tonsillitis [20]. NO is hypothesized to be 
involved in tissue damage in autoimmune skin diseases such as psoriasis and patients with psoriatic arthritis have higher levels of FeNO than those with psoriasis only [21,22]. Acute and chronic tobacco smoking reduces FeNO levels [12].

It is still unclear whether exhaled NO levels change in a significant way during infections in asthmatic patients. Using FeNO levels seems to be unhelpful in distinguishing viral and bacterial infections. The presence of atopy (proved in children) and allergic rhinitis (both in children and adults) is associated with higher FeNO levels [12,23]. High NO production is not an effect of atopy but it results from exposure to allergens and secondary allergic inflammation [24].

Airway inflammation can be assessed noninvasively with eNO measurement. FeNO correlated significantly with bronchial hyperresponsiveness (BHR) in atopic patients with asthmatic symptoms [19]. Asero et Madonini [25] proved increased BHR in most urticaria patients, contrary to the study results of Anania and Striglia [26]. Petalas et al. [27] draw attention to the BHR in patients with cholinergic urticaria. This phenomenon is explained by the systemic release of bronchial inflammation mediators from eosinophils, basophils and mast cells $[25,27,28]$. Following the idea of possible BHR in urticaria patients, we hypothesized increased eNO in those patients. To date, there have been no reports on eNO level in CSU patients. Furthermore, no information is available on the relationship between upper airway angioedema and eNO. Although an inflammatory baseline or trigger is not necessary for hereditary angioedema (HAE) presentation-increased eNOS levels in serum are reported in HAE [29]. Since chronic spontaneous urticaria (CSU) and angioedema is characterized as an inflammatory disorder, we aimed to analyze eNO levels in the course of acute upper airway angioedema symptoms.

\section{Material and Methods}

We examined thirty four consecutive non-smoking chronic spontaneous urticaria patients referred to our department because of the symptoms of acute pharynx angioedema (endotracheal intubation was not required). In eNO measurement, we used Niox Mino ${ }^{\circledR}$ analyser (Aerocrine AB, Solna, Sweden) with the measurement range 5 to 300 parts per billion (ppb). Its usefulness in clinical studies has already been proven [30]. The subjects were studied in the sitting position. Measurements were performed before the administration of glucocorticoids. None of the patients had been treated with steroids or antihistamine drugs in the three months preceding the analysis. Finally, 26 patients (17 women and 9 men; median age 35 years) were included in our study. On the basis of subsequent diagnostic procedures (skin prick tests, total IgE, paranasal sinuses computed tomography and ENT assessment) these patients were characterized as nonatopic and did not reveal any laboratory and clinical features of infection. In all examined patients lung function parameters were normal, none of them reported a history of asthma or allergic rhinitis. Additionally, known underlying reasons of edema (i.e., ACE inhibitors usage, C1 esterase deficiency) were excluded. The disease duration period was from 4 months to 5 years.

The control group consisted of 29 non-smoking healthy (based on medical history and physical examination) subjects (19 women and 10 men; median age 22 years). These subjects presented normal lung function parameters, did not reveal any history of atopy (confirmed with negative results of skin prick tests), and no clinical and laboratory features of airway infection.

\section{Statistical Analysis}

The statistical analysis was performed with the nonparametric U Mann-Whitney test. A $p$ value of $<0.05$ was considered to be statistically significant.

\section{Results}

As shown in Table 1 and Figure 1, eNO levels in angioedema group did not differ statistically significantly from those detected in healthy subjects (median value $15.5 \mathrm{ppb}$ and $17.0 \mathrm{ppb}$ respectively; $p=0.45$ ). 
Table 1. Exhaled nitric oxide (FeNO) level and age of angioedema patients in comparison to healthy controls.

\begin{tabular}{|c|c|c|c|}
\hline Analysed Parameters & $\begin{array}{l}\text { Healthy Controls } \\
\qquad(\mathrm{N}=29)\end{array}$ & $\begin{array}{l}\text { Angioedema } \\
\text { Patients } \\
(\mathrm{N}=26)\end{array}$ & Statistical Analysis \\
\hline (Unit) & $\begin{array}{c}\text { Median } \\
\text { Range } \\
25-75 \%\end{array}$ & $\begin{array}{l}\text { Median } \\
\text { Range } \\
25-75 \%\end{array}$ & $p$ \\
\hline $\begin{array}{l}\text { eNO } \\
(\mathrm{ppb})\end{array}$ & $\begin{array}{c}17.0 \\
9.00-27.0 \\
13.0-20.0\end{array}$ & $\begin{array}{c}15.5 \\
5.00-37.0 \\
11.0-19.0\end{array}$ & 0.45 \\
\hline $\begin{array}{c}\text { age } \\
\text { (years) }\end{array}$ & $\begin{array}{c}22.0 \\
21.0-58.0 \\
22.0-48.0\end{array}$ & $\begin{array}{c}35.0 \\
18.0-60.0 \\
25.0-50.0\end{array}$ & 0.39 \\
\hline
\end{tabular}

\begin{tabular}{|c|c|c|c|}
\hline \multicolumn{4}{|c|}{40} \\
\hline 35 & • & & \\
\hline 30 & . & & \\
\hline$\sigma^{25}$ & : & $\vdots$ & \\
\hline $\begin{array}{l}\text { 을 } 20 \\
\text { 일 } 15\end{array}$ & $\vdots$ & : & $p=0.45$ \\
\hline 10 & $\vdots$ & $\vdots$ & \\
\hline 5 & . & & \\
\hline 0 & edema & ontrol & \\
\hline
\end{tabular}

Figure 1. Individual exhaled nitric oxide (FeNO) level in angioedema patients in comparison to healthy subjects. FeNO—exhaled nitric oxide, NO—nitric oxide, ppb—parts per billion.

\section{Discussions}

Increased NO in exhaled air is a phenomenon accompanying many disorders. Besides the above-mentioned, it was proven in systemic lupus erythematosus, whereas iNOS was supposed to play an important role in Crohn's disease and ulcerative colitis [5,31-33]. In non-lesional skin biopsies of patients suffering from systemic lupus erythematosus, iNOS expression in endothelial cells and keratinocytes was demonstrated [34]. NO synthase inhibition is even hypothesized to be a treatment strategy in different diseases, including those involving autoimmune mechanisms in their pathogenesis [2,5,35-37]. The production of NO is increased in various skin diseases (atopic dermatitis, contact dermatitis, psoriasis) [22]. In atopic dermatitis patients, the increased serum nitrate level was found, which suggests $\mathrm{NO}$ role in vasodilatation associated with skin erythema and edema [38].

eNOS is known to increase in patients with HAE both in the attack and in the remission phase and there are reports of significant differences in levels of other vasoactive mediatorsvascular endothelial growth factors (VEGFs), angiopoietins (ANGPTs) and phospholipase A2 enzymes ( $\left.\mathrm{PLA}_{2}\right)[29,39]$. We cannot exclude that the edema of the pharynx of studied patients was due to an increased vascular permeability of eNOS as a consequence of an inflammatory state induced by proinflammatory cytokines released by mast cells.

NO level can be suppressed by corticosteroids as an effect of proinflammatory cytokine inhibition or direct influence on iNOS [40]. FeNO levels decrease in response to systemic steroid treatment of asthma exacerbation and as an effect of inhaled corticosteroid therapy [12]. Cytokines, immune complexes and complement activation products can be the factors upregulating iNOS in the epithelium, the endothelium, alveolar macrophages 
and smooth muscle cells [2]. In general proinflammatory cytokines, such as TNF- $\alpha$, IL-1, IFN- $\gamma$ and LPS induce iNOS levels [2]. On the contarary, most of FeNO in the airways is produced as a consequence of iNOS being stimulated by IL-4 and IL-13 [12,41]. Different cytokines are suspected to be involved in the pathogenesis of CSU (incl. IL-4, IL-6, IL-13, IL-17) [42-45]. Increase in IL-4 serum level was observed in both acute urticaria [46] and CSU [42]. Bae et al. [43] observed significantly higher levels of IL-13 in CSU. Among potential drugs that could be used in CSU treatment are anti-IL-4 and anti-IL-13 [47]. Decrease in different cytokines levels (including IL-4) and limiting iNOS production of NO is observed after treatment of allergic diseases with antyhistamines [48,49].

The increased eNO level in liver cirrhosis patients noticed by Matsumoto et al. [50] was hypothesized to be an effect of elevated concentrations of serum cytokines. Becherel et al. [8] proved iNOS mRNA expression in biopsies of acute urticaria lesional skin and its relation to proinflammatory cytokines [8]. They even hypothesized the role of iNOS inhibitors in the management of severe acute urticaria and some chronic forms [8]. Inducible NOS stimulation by proinflammatory cytokines that are involved in urticaria pathogenesis could result in the increased NO level in exhaled air in urticaria and angioedema patients $[12,19,21,51]$. Moreover, the increased eNO might be speculated as increased bronchial hyperresponsiveness related to this phenomenon $[25,27,28]$. Such hyperresponsiveness was supposed to be found in CSU [25].

Our results did not confirm the above hypothesis. No marked relationship between pharynx angioedema symptoms in CSU and increased FeNO levels was found. It may be speculated that the location of edema in the lower mucous membrane layers in the course of upper airway angioedema results in impaired diffusion of $\mathrm{NO}$ into the airways. The airway wall forms a barrier of NO diffusion [16,52]. This phenomenon is taken into account when explaining only a slight elevation in FeNO in other inflammatory disorders [12,16,52].

Pathophysiology of chronic urticaria includes wide spectrum of immune and inflammatory components, although some hormonal abnormalities and psychological components should also be taken into account [53-56].

\section{Conclusions}

The results of our study bring some more data concerning the problem of airway inflammation in chronic urticaria and angioedema patients. In our opinion, a further study concerning extended exhaled nitric oxide analysis and the NO in skin biopsies of the chronic urticaria patients should be both interesting and informative. Verifying alteration in levels of vasoactive mediators, preferably in different points in time and comparison with existing data in other conditions of similar clinical presentation could broaden the knowledge of the mechanisms underlying angioedema attack.

Author Contributions: Conceptualization: Z.B.; Methodology: Ł.M., Z.B.; Formal analysis: Ł.M., Z.B.; Investigation: M.Z., Z.B.; Data curation: M.Z., Z.B.; Writing—original draft preparation: Ł.M., Z.B.; Writing-review and editing: Ł.M., M.Z., Z.B. All authors have read and agreed to the published version of the manuscript.

Funding: This research received no external funding.

Institutional Review Board Statement: The study was conducted according to the guidelines of the Declaration of Helsinki, and approved by the Ethics Committee of the Medical University of Silesia, Katowice, Poland (KNW/0022/KB1/18/15).

Informed Consent Statement: Informed consent was obtained from all subjects involved in the study.

Data Availability Statement: The data that support the findings of this study are available from the corresponding author, (ZB), upon reasonable request.

Conflicts of Interest: The authors declare no conflict of interest. 


\section{References}

1. Coleman, J.W. Nitric oxide: A regulator of mast cell activation and mast cell-mediated inflammation. Clin. Exp. Immunol. 2002, 129, 4-10. [CrossRef] [PubMed]

2. Cinelli, M.A.; Do, H.T.; Miley, G.P.; Silverman, R.B. Inducible nitric oxide synthase: Regulation, structure, and inhibition. Med. Res. Rev. 2020, 40, 158-189. [CrossRef] [PubMed]

3. Cals-Grierson, M.M.; Ormerod, A.D. Nitric oxide function in the skin. Nitric Oxide-Biol. Chem. 2004, 10, 179-193. [CrossRef] [PubMed]

4. Claesson-Welsh, L. Vascular permeability-The essentials. Ups. J. Med. Sci. 2015, 120, 135-143. [CrossRef]

5. Abramson, S.B.; Amin, A.R.; Clancy, R.M.; Attur, M. The role of nitric oxide in tissue destruction. Best Pract. Res. Clin. Rheumatol. 2001, 15, 831-845. [CrossRef] [PubMed]

6. Kröncke, K.D.; Fehsel, K.; Kolb-Bachofen, V. Inducible nitric oxide synthase in human diseases. Clin. Exp. Immunol. 1998, 113, 147-156. [CrossRef]

7. Förstermann, U.; Sessa, W.C. Nitric oxide synthases: Regulation and function. Eur. Heart J. 2012, 33, 829. [CrossRef]

8. Bécherel, P.A.; Chosidow, O.; Le Goff, L.; Francès, C.; Debré, P.; Mossalayi, M.D.; Arock, M. Inducible nitric oxide synthase and proinflammatory cytokine expression by human keratinocytes during acute urticaria. Mol. Med. 1997, 3, 686-694. [CrossRef]

9. Pinke, K.H.; de Lima, H.G.; Cunha, F.Q.; Lara, V.S. Mast cells phagocyte Candida albicans and produce nitric oxide by mechanisms involving TLR2 and Dectin-1. Immunobiology 2016, 221, 220-227. [CrossRef]

10. de Lima, H.G.; Pinke, K.H.; Lopes, M.M.R.; Buzalaf, C.P.; Campanelli, A.P.; Lara, V.S. Mast cells exhibit intracellular microbicidal activity against Aggregatibacter actinomycetemcomitans. J. Periodontal Res. 2020, 55, 744-752. [CrossRef]

11. Park, E.-A.; Han, I.-H.; Kim, J.-H.; Park, S.-J.; Ryu, J.-S.; Ahn, M.-H. Production of Inflammatory Cytokines and Nitric Oxide by Human Mast Cells Incubated with Toxoplasma gondii Lysate. Korean J. Parasitol. 2019, 57, 201. [CrossRef] [PubMed]

12. Pignatti, P.; Visca, D.; Loukides, S.; Märtson, A.G.; Alffenaar, J.W.C.; Migliori, G.B.; Spanevello, A. A snapshot of exhaled nitric oxide and asthma characteristics: Experience from high to low income countries. Pulmonology 2020, 28, 44-58. [CrossRef] [PubMed]

13. Galiniak, S.; Rachel, M. Comparison of fractional exhaled nitric oxide in asthmatics with and without allergic rhinitis. Biomarkers 2021, 26, 174-183. [CrossRef] [PubMed]

14. Rachel, M.; Biesiadecki, M.; Aebisher, D.; Galiniak, S. Exhaled nitric oxide in pediatric patients with respiratory disease. J. Breath Res. 2019, 13, 046007. [CrossRef] [PubMed]

15. Dinh-Xuan, A.T.; Annesi-Maesano, I.; Berger, P.; Chambellan, A.; Chanez, P.; Chinet, T.; Degano, B.; Delclaux, C.; Demange, V.; Didier, A.; et al. Contribution of exhaled nitric oxide measurement in airway inflammation assessment in asthma. A position paper from the French Speaking Respiratory Society. Rev. Mal. Respir. 2015, 32, 193-215. [CrossRef] [PubMed]

16. Cameli, P.; Bargagli, E.; Bergantini, L.; D'Alessandro, M.; Pieroni, M.; Fontana, G.A.; Sestini, P.; Refini, R.M. Extended Exhaled Nitric Oxide Analysis in Interstitial Lung Diseases: A Systematic Review. Int. J. Mol. Sci. 2020, 21, 6187. [CrossRef]

17. Kharitonov, S.A.; Wells, A.U.; O'Connor, B.J.; Cole, P.J.; Hansell, D.M.; Logan- Sinclair, R.B.; Barnes, P.J. Elevated levels of exhaled nitric oxide in bronchiectasis. Am. J. Respir. Crit. Care Med. 1995, 151, 1889-1893. [CrossRef]

18. Rizzi, M.; Radovanovic, D.; Airoldi, A.; Cristiano, A.; Frassanito, F.; Gaboardi, P.; Saad, M.; Atzeni, F.; Sarzi-Puttini, P.; Santus, P. Rationale underlying the measurement of fractional exhaled nitric oxide in systemic sclerosis patients. Clin. Exp. Rheumatol. 2019, 37 (Suppl. 1), 125-132.

19. Terrington, D.L.; Hayton, C.; Peel, A.; Fowler, S.J.; Fraser, W.; Wilson, A.M. The role of measuring exhaled breath biomarkers in sarcoidosis: A systematic review. J. Breath Res. 2019, 13, 036015. [CrossRef]

20. Kasperska-Zajac, A.; Brzoza, Z.; Czecior, E.; Rogala, B.; Polok, A.; Namyslowski, G. Elevated levels of exhaled nitric oxide in recurrent tonsillitis. Eur. Respir. J. 2008, 31, 909-910. [CrossRef]

21. Damiani, G.; Pacifico, A.; Rizzi, M.; Santus, P.; Bridgewood, C.; Bragazzi, N.L.; Adawi, M.; Watad, A. Patients with psoriatic arthritis have higher levels of FeNO than those with only psoriasis, which may reflect a higher prevalence of a subclinical respiratory involvement. Clin. Rheumatol. 2020, 39, 2981-2988. [CrossRef] [PubMed]

22. Santus, P.; Rizzi, M.; Radovanovic, D.; Airoldi, A.; Cristiano, A.; Conic, R.; Petrou, S.; Pigatto, P.D.M.; Bragazzi, N.; Colombo, D.; et al. Psoriasis and Respiratory Comorbidities: The Added Value of Fraction of Exhaled Nitric Oxide as a New Method to Detect, Evaluate, and Monitor Psoriatic Systemic Involvement and Therapeutic Efficacy. Biomed Res. Int. 2018, 2018, 3140682. [CrossRef] [PubMed]

23. Linhares, D.; Jacinto, T.; Pereira, A.M.; Fonseca, J.A. Effects of atopy and rhinitis on exhaled nitric oxide values-A systematic review. Clin. Transl. Allergy 2011, 1, 8. [CrossRef] [PubMed]

24. Olin, A.C.; Alving, K.; Torén, K. Exhaled nitric oxide: Relation to sensitization and respiratory symptoms. Clin. Exp. Allergy 2004, 34, 221-226. [CrossRef] [PubMed]

25. Asero, R.; Madonini, E. Bronchial hyperresponsiveness is a common feature in patients with chronic urticaria. J. Investig. Allergol. Clin. Immunol. 2006, 16, 19-23.

26. Anania, A.; Striglia, E. Bronchial reactivity in subjects with urticaria. Panminerva Med. 1999, 41, 311-313.

27. Petalas, K.; Kontou-Fili, K.; Gratziou, C. Bronchial hyperresponsiveness in patients with cholinergic urticaria. Ann. Allergy Asthma Immunol. 2009, 102, 416-421. [CrossRef] 
28. Henz, B.M.; Jeep, S.; Ziegert, F.S.; Niemann, J.; Kunkel, G. Dermal and bronchial hyperreactivity in urticarial dermographism and urticaria factitia. Allergy Eur. J. Allergy Clin. Immunol. 1996, 51, 171-175. [CrossRef]

29. Demirtürk, M.; Gelincik, A.; Çinar, S.; Kilercik, M.; Onay-Ucar, E.; Çolakoğlu, B.; Arda, N.; Büyüköztürk, S.; Deniz, G. Increased eNOS levels in hereditary angioedema. Int. Immunopharmacol. 2014, 20, 264-268. [CrossRef]

30. Chen, W.; Purohit, A.; Barnig, C.; Casset, A.; De Blay, F. Niox ${ }^{\circledR}$ and Niox Mino ${ }^{\circledR}$ : Comparison of exhaled NO in grass pollen allergic adult volunteers. Allergy Eur. J. Allergy Clin. Immunol. 2007, 62, 571-572. [CrossRef]

31. Rolla, G.; Brussino, L.; Bertero, M.T.; Colagrande, P.; Converso, M.; Bucca, C.; Polizzi, S.; Caligaris-Cappio, F. Increased nitric oxide in exhaled air of patients with systemic lupus erythematosus. J. Rheumatol. 1997, 24, 1066-1071. [PubMed]

32. Binion, D.G.; Fu, S.; Ramanujam, K.S.; Chai, Y.C.; Dweik, R.A.; Drazba, J.A.; Wade, J.G.; Ziats, N.P.; Erzurum, S.C.; Wilson, K.T. iNOS expression in human intestinal microvascular endothelial cells inhibits leukocyte adhesion. Am. J. Physiol.-Gastrointest. Liver Physiol. 1998, 275, G592-G603. [CrossRef] [PubMed]

33. Vento, P.; Kiviluoto, T.; Järvinen, H.J.; Soinila, S. Changes in distribution of three isoforms of nitric oxide synthase in ulcerative colitis. Scand. J. Gastroenterol. 2001, 36, 180-189. [CrossRef] [PubMed]

34. Belmont, H.M.; Levartovsky, D.; Goel, A.; Amin, A.; Giorno, R.; Rediske, J.; Skovron, M.L.; Abramson, S.B. Increased nitric oxide production accompanied by the up-regulation of inducible nitric oxide synthase in vascular endothelium from patients with systemic lupus erythematosus. Arthritis Rheum. 1997, 40, 1810-1816. [CrossRef]

35. Heemskerk, S.; Masereeuw, R.; Russel, F.G.M.; Pickkers, P. Selective iNOS inhibition for the treatment of sepsis-induced acute kidney injury. Nat. Rev. Nephrol. 2009, 5, 629-640. [CrossRef] [PubMed]

36. Camuesco, D.; Comalada, M.; Rodríguez-Cabezas, M.E.; Nieto, A.; Lorente, M.D.; Concha, A.; Zarzuelo, A.; Gálvez, J. The intestinal anti-inflammatory effect of quercitrin is associated with an inhibition in iNOS expression. Br. J. Pharmacol. 2004, 143, 908-918. [CrossRef]

37. Ekmekcioglu, S.; Grimm, E.A.; Roszik, J. Targeting iNOS to increase efficacy of immunotherapies. Hum. Vaccines Immunother. 2017, 13, 1105-1108. [CrossRef]

38. Taniuchi, S.; Kojima, T.; Hara Mt, K.; Yamamoto, A.; Sasai, M.; Takahashi, H.; Kobayashi, Y. Increased serum nitrate levels in infants with atopic dermatitis. Allergy Eur. J. Allergy Clin. Immunol. 2001, 56, 693-695. [CrossRef]

39. Ferrara, A.L.; Bova, M.; Petraroli, A.; Veszeli, N.; Galdiero, M.R.; Braile, M.; Marone, G.; Cristinziano, L.; Marcella, S.; Modestino, L.; et al. Hereditary angioedema attack: What happens to vasoactive mediators? Int. Immunopharmacol. 2020, 78, 17-22. [CrossRef]

40. Kharitonov, S.A.; Barnes, P.J. State of the Art Exhaled Markers of Pulmonary Disease. Am. J. Respir. Crit. Care Med. 2001, 163, 1693-1722. [CrossRef]

41. Chibana, K.; Trudeau, J.B.; Mustovitch, A.T.; Hu, H.; Zhao, J.; Balzar, S.; Chu, H.W.; Wenzel, S.E. IL-13 induced increases in nitrite levels are primarily driven by increases in inducible nitric oxide synthase as compared with effects on arginases in human primary bronchial epithelial cells. Clin. Exp. Allergy 2008, 38, 936-946. [CrossRef] [PubMed]

42. Ferrer, M.; Luquin, E.; Sanchez-Ibarrola, A.; Moreno, C.; Sanz, M.L.; Kaplan, A.P. Secretion of cytokines, histamine and leukotrienes in chronic urticaria. Int. Arch. Allergy Immunol. 2002, 129, 254-260. [CrossRef] [PubMed]

43. Bae, Y.; Izuhara, K.; Ohta, S.; Ono, J.; Hong, G.U.; Ro, J.Y.; Park, G.H.; Choi, J.H. Periostin and Interleukin-13 Are Independently Related to Chronic Spontaneous Urticaria. Allergy. Asthma Immunol. Res. 2016, 8, 457-460. [CrossRef] [PubMed]

44. Toubi, E.; Vadasz, Z. The Emerging Role of IL-17 in the Immune-Pathogenesis of Chronic Spontaneous Urticaria. ImmunoTargets Ther. 2020, 9, 217-223. [CrossRef] [PubMed]

45. Kasperska-Zajac, A.; Brzoza, Z.; Rogala, B. Plasma concentration of interleukin 6 (IL-6), and its relationship with circulating concentration of dehydroepiandrosterone sulfate (DHEA-S) in patients with chronic idiopathic urticaria. Cytokine 2007, 39, 142-146. [CrossRef]

46. Zheng, R.; Qian, L.; Yu, J.; Li, M.; Qian, Q. Analysis of the changes in Th9 cells and related cytokines in the peripheral blood of spontaneous urticaria patients. Biomed. Rep. 2017, 6, 633-639. [CrossRef]

47. Kocatürk, E.; Maurer, M.; Metz, M.; Grattan, C. Looking forward to new targeted treatments for chronic spontaneous urticaria. Clin. Transl. Allergy 2017, 7, 1. [CrossRef]

48. Axelrod, D.; Bielory, L. Fexofenadine hydrochloride in the treatment of allergic disease: A review. J. Asthma Allergy 2008, 1, 19-29.

49. Zheng, D.; Yang, X. Clinical observation on the therapeutic effect of desloratadine citrate disodium in the treatment of chronic urticaria and changes in IL4, IL18, IL23 and IL-33 levels before and after treatment. Pak. J. Pharm. Sci. 2017, 30, 1139-1142.

50. Matsumoto, A.; Ogura, K.; Hirata, Y.; Kakoki, M.; Watanabe, F.; Takenaka, K.; Shiratori, Y.; Momomura, S.I.; Omata, M. Increased nitric oxide in the exhaled air of patients with decompensated liver cirrhosis. Ann. Intern. Med. 1995, 123, 110-113. [CrossRef]

51. Änggård, E. Nitric oxide: Mediator, murderer, and medicine. Lancet 1994, 343, 1199-1206. [CrossRef]

52. Húgman, M.; Holmkvist, T.; Wegener, T.; Emtner, M.; Andersson, M.; Hedenstrúm, H.; Meriløinen, P. Extended NO analysis applied to patients with COPD, allergic asthma and allergic rhinitis. Respir. Med. 2002, 96, 24-30. [CrossRef] [PubMed]

53. Brzoza, Z.; Kasperska-Zajac, A.; Badura-Brzoza, K.; Matysiakiewicz, J.; Hese, R.T.; Rogala, B. Decline in Dehydroepiandrosterone Sulfate Observed in Chronic Urticaria is Associated With Psychological Distress. Psychosom. Med. 2008, 70, 723-728. [CrossRef] [PubMed] 
54. Kasperska-Zajac, A.; Brzoza, Z.; Rogala, B. Lower serum concentration of dehydroepiandrosterone sulphate in patients suffering from chronic idiopathic urticaria. Allergy 2006, 61, 1489-1490. [CrossRef]

55. Kasperska-Zajac, A.; Brzoza, Z.; Rogala, B. Serum concentration of dehydroepiandrosterone sulphate in female patients with chronic idiopathic urticaria. J. Dermatol. Sci. 2006, 41, 80-81. [CrossRef]

56. Brzoza, Z.; Kasperska-Zajac, A.; Rogala, B. Serum prolactin concentration and its relationship with dehydroepiandrosterone sulfate concentration in chronic urticaria patients with positive and negative response to autologous serum skin test. Allergy 2007, 62, 566-567. [CrossRef] 